\title{
The Role of Family in Islamic Education in the New Normal Area
}

Nurul Huda ZH Harahap ${ }^{1}$, Elis Ariska², Nikmah Hidayati Harahap ${ }^{3}$, Larasati Nur Kharomah ${ }^{4}$ $1,2,3,4$ Universitas Islam Negeri Sumatera Utara, Indonesia

\begin{tabular}{|c|c|}
\hline ARTICLE INFO & ABSTRACT \\
\hline Article history: & \multirow{6}{*}{$\begin{array}{l}\text { Family is the first education for children. In the neigbhourhood the } \\
\text { child gets the influence, because that is the family is the highest } \\
\text { educational institution. It is in this family that the child gets care } \\
\text { from the parents heading in the direction its development. Before a } \\
\text { child knows the environment, the social, the school and the outside } \\
\text { world. He was first influenced by his family environment, especially } \\
\text { his parents. This research methode uses qualitative approach, with a } \\
\text { purpose to obtain data related to Islamic education within } \\
\text { community. This research more focuses on role of the parents } \\
\text { themselves in Islamic education in the new normal era. Basic } \\
\text { conclusion obtained from this research is parents who have } \\
\text { significant role in educating their children. The first thing is very } \\
\text { important implanted in yourselves sons of the in the process of } \\
\text { education first this is planting religious values .Its very important as } \\
\text { early as possible in yourselves sons of the basic must be built strong } \\
\text { religious provide financial support for him to lived his life. }\end{array}$} \\
\hline $\begin{array}{l}\text { Received April 20, } 2020 \\
\text { Revised Jun 02, 2020 } \\
\text { Accepted Sept 02, } 2020\end{array}$ & \\
\hline Keywords: & \\
\hline $\begin{array}{l}\text { Parent's role, } \\
\text { Islamic Education, } \\
\text { New Normal Era, }\end{array}$ & \\
\hline Clonflict of Interest: & \\
\hline & \\
\hline
\end{tabular}

Funding:

None

Corresponding Author: Nurul Huda ZH Harahap. Tel: +62-831-2493-1679. E-mail: hudan9282@gmail.com.

\section{Introduction}

\subsection{Background}

For several months, parents have been assisting children to learn since the government implemented a learning system at home to suppress the spread of COVID-19. Although these conditions make some parents feel overwhelmed, but this encourages them to be actively involved in the teaching and learning process of children. In addition, researchers see the activity of guiding children to learn at home indirectly encouraging parents to communicate better with the teacher, getting to know the child's character more fully, and becoming more accustomed to discussing children's emotional issues that were previously avoided.

Why do parents need to take a greater role in online learning? We need to remember the teaching of the father of education,"Ki Hajar Dewantara about Tri Pusat Pendidikan", namely education received by students from three environments. : Family, school, and community. The role of the parents in the environtment family and acctually that is where education is the most important. A famous poet, Hafiz Ibrahim revealed" Al- Umm Madrasatul'Ula" It means that, mother is the first school for her child. Everything from children strats from the family, from parents. Especially if learning is done at home or if the goverment enter gives a policy decision on re-learning in schools with a health protocol and students enter the shift system for physical distancing. 
Especially in fostering Islamic Education in a child. In modern era alomost parents are more concerned with general science education than religious and moral science for their children. This is evidence by the discovery of early childhood who experience early maturity and have a mindset that is far more mature than their age. This phenomenon is growing rapidly supported by the sophistication of information and communication technology that is noot matched by the parental control, so that modern sociocultral influences quickly penetrate into the child's psyche which result in children imitating the behaviour of what they are witnessing.

The role and guidance of Islamic education in children according to the active role of their families can not be ignored. It is a the most of mistake to hand over the formation of children's Islamic education to the environtment, the community or the school. This is due to the responsibility of the earliest religious education for children located on the shoulders of their parents. To achieve this goal, parents should realize the importance of education for their children, especially education that has to do with the values of Islamic education. Because it is all the responsibility of parents fo the generation that was born.

Allah says:

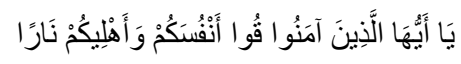

O you who have believed, Protect yourselves and your families from the fires of hell. . . (QS At-Tahrim verse 6). Also the words of the Messenger of Allah:

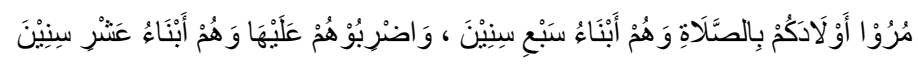

"Order your children to pray when they are seven years old, and beat them if they do not want to pray when they are ten years old" (HR. Abu Daud, Al Turmuzi, Ahmad and Al Hakim). The meaning contained in the hadith and the word shows that parents have a very important role in giving confidence in religious values, morals and skills to a child. therefore, parents should play a role in providing religious education in the family, as the results of research conducted by Djaelani which states that, Islamic religious education is the foundation in the family to shape children's behavior and morals and know the boundaries of good and bad and serves to forming people who believe in and devotion to Allah SWT.

From the description above the researcher try to examine how the role of parents in Islamic education in this new normal era.

\section{Literature Review}

\subsection{Education in the New Normal Era}

Some of us are certainly familiar with the term New Normal. Importantly, the term has been heralded quite often over the past few weeks, in response to the corona virus pandemic which has not yet shown signs of ending, more in Indonesia. Now, all sectors are prepared considering the new life in question, including the education world. Starting from how to do activities at home to create a pleasant atmosphere while studying.

The implementation of social distancing as the main factor of New Normal itself however creates its own challenges for those working in the world of education. Education is a conscious effort made by humans in creating an atmosphere of learning to shape and develop students' attitudes that are in accordance with applicable norms, so that schools can act as institutions that can prepare children both academically and moral agents in society (Mulyadi et al., 2019). Education itself will not be separated from family, school, and community life (Sada, 2017). Education is a way to improve the quality of human life in all aspects of life, for example by instilling morals in humans (Suryadarma \& Haq, 2015). In this new normal era, parents are demanded more in educating children. Therefore the role of parents is very important in the learning process of children in this new normal era, especially in Islamic religious education. As the results of research conducted by Djaelani which states that, Islamic education is the foundation in the family to shape the behavior and morals of children and know the boundaries of good and bad, and serves to form humans who believe in and devotion to Allah SWT.

\subsection{The Role of Parents in Islamic Education}

Parents are the first people known to children. It is through parents that children get first impressions about the outside world. Parents are the first people to guide behavior. Against the behavior of their children react by accepting, agreeing, justifying, rejecting, or prohibiting and so on. By assigning values to this behavior, norms are formed about what is good and bad, what is permissible or not. Thus the child's conscience is formed which directs subsequent behavior. The obligation of parents is to develop a strong conscience in children. 
Islamic religious education, in essence is an effort to direct, guide all aspects (potential) that exist in humans optimally (Rohman, 2009: 34-36). The basics that become the strength of religious education (Islam) are the Qur'an and Sunnah. Education in Islam is said by Ahmad D. Marimba (1989: 43), namely the word of God and the Apostle, like education as a building, then the contents of the Qur'an and Sunna as a guide.

The role of parents on children's education must be done continuously, from the beginning the child has been prepared to live in an Islamic atmosphere so that when he grows up he can become a guide in his life and not fall into things that are forbidden by religion. Every parent, educator and teacher is essentially carrying out God's mandate. Because they will be held responsible by God about how the education of their children. (Abu Tauhid, 1990: 5). Parents need to realize how important religious education is for each family member, especially for children. Religious education which is instilled as early as possible to children has a very positive influence on the growth and development of their character and personality. Therefore parents are obliged to provide guidance and concrete examples of role models to children how one must carry out religious teachings in the family, so that they are safe and prosperous.

\section{Method}

This type of research is descriptive qualitative research. Data collection methods used are observation, interviews, and documentation. Data collection instruments used were observation guidelines, interview guidelines, and checklist. The data collected is then processed and analyzed with the following steps: data reduction, data presentation, and data verification.

\section{Results and Discussion}

In this new normal era, parents are demanded more in educating children. Therefore the role of parents is very important in the learning process of children in this new normal era especially in Islamic religious education. Parents also show as far as possible the friendly attitude and familiarity of children who provide a comfortable attitude in the learning process in this new normal era. In the process of learning Islamic religious education must be done continuously in order to foster a strong religious value. Children's trust grows through the exercises and the education they receive in their environment. Examples such as: Getting used to pray when you want to sleep, when you want to eat and drink, and pray five times a day.

Parents need to provide guidance to their children in order to be able to solve the problem at hand. Some things parents can do are first, to help children understand their respective positions and roles, so that they can respect each other and help one another in carrying out good deeds; second, parents must help their children to know and understand the values that govern family life, neighbors, community and are able to carry it out in life; third, parents should encourage their children to seek world knowledge and religious knowledge, in order to be able to realize themselves (self realization) as individuals and faithful members of society; fourth, helping children enter community life step by step to free themselves from dependence on parents, and take responsibility for their attitudes and behavior; fifth, help provide opportunities and encourage children to do their own work and participate in carrying out religious activities in the family and the community to gain their own experience directly as an effort to increase faith and the spread of the message (Mansur, 2009: 349-350).

\subsection{The Efforts of Parents to Instill Islamic Education}

The efforts made by people in instilling Islamic education in this new normal era:

1. Familiarize children in praying and reciting the Koran. In familiarizing children with good behavior, noble examples are needed such as prayer in congregation, reciting certain readings and prayers, for example, also saying greetings when going to the house and going or reading basmalah when going to start every job. This can be successful if parents provide leadership and role models every day. Parental behavior should be a manifestation of religious education in him. If this can be done then even the children will behave like what their parents did (Reza, 2002)

2. Avoid children from family gatherings in which discuss something despicable so that children follow these actions, such as calamity or gossip, jealousy, jealousy, greedy, indecent and mutilation or other disgraceful speech.

3. Instilling true faith and faith in children.

4. Instill praiseworthy values and noble morals in themselves and keep them away from despicable morals

5. Teach them good deeds and train them so that they can practice them in their daily lives. 


\section{Conclusion}

The family is an educational institution that is most responsible for their children, should always pay attention and guide their children, especially guidance and education related to the values of Islamic religious education because it is key. Because religious education plays a major role in shaping one's outlook on life. In modern times like today almost most parents are more concerned with general science education than religious and moral science for their children. This is evidenced by the discovery of early childhood who experience early maturity and have a mindset that is far more mature than their age. Therefore parents are obliged to provide guidance and concrete examples of role models to children how one must carry out religious teachings in the family.

The role of parents as the first and foremost educators who instill the basis for children's mental development. Religious education should be able to color the child's personality, so that religion really becomes part of his personality which will be the controller in his life in the future. In order to achieve the formation of a good personality, religious education should be given by parents who are truly reflected in religion in attitudes, behavior, gestures, how to dress, how to speak, how to deal with problems and in the whole person. In short it can be said that religious education will be successful if religious teachings live and are reflected in the person of the parents themselves.

The COVID-19 pandemic provides many lessons for all of us, especially in the field of education, teachers and parents are required to get used to using technology to find information and communicate. With the use of technology in learning, it is hoped that learning will be more directed at continuous, effective-efficient, correct and objective improvement efforts. Although these conditions make some parents feel overwhelmed, but this encourages them to be actively involved in the teaching and learning process of children.

Education in the family is a coaching effort undertaken by parents of children so that they can grow and develop as they should. Parents are the central teacher in the family because every child gets his first education and usually the most imprint is from his parents. The educational process given by parents to their children can be through several (non-physical) educational tools, namely exemplary, habituation, punishment and reward and supervision.

\section{References}

Departemen Agama RI. (2004). Al - Qur'an dan Terjemahnya. Jakarta: Proyek Peningkatan Pelayanan Kehidupan Beragama Pusat Ditjen Bimas Islam dan Penyelenggara Haji, h, 820.)

Djaelani, S. (2011). Peran Pendidikan Agama Dalam Keluarga. Jurnal Widya.

Sada, H. J. (2017). Peran Masyrakat alam Pendidikan Perspektif Pendidikan Islam. Al-Tadzkiyyah: Jurnal Pendidikan Islam, 8(1), 117-125.

Mulyadi, D. Sapriya, \& Rahmat (2019). Kajian Tentang Penumbuhan Karakter Jujur Peserta Didik Sebagai Upaya Pengembangan Dimensi Budaya Kewarganegaraan (Civic Culture) di SMA Alfa Centauri Bandung. Modeling: Jurnal Program Studi PGMI, 6(2), 220-232.

Suryadarma, Y. \& Haq, A. H. (2015) Pendidikan Akhlak Menurut Imam AL-Ghazali. Jurnal At-Ta'dib, 10(2).

Arif Rohman (2009). Memahami Pendidikan dan Ilmu Pendidikan. Yogyakarta: LaksBang Mediatama.

Marimba, Ahmad D. (1981). Filsafat Pendidikan Islam. Bandung: PT AlMaeearif.

Abu Tauhid, H. (1990). Beberapa Aspek Pendidikan Islam. Yogyakarta: Fakultas Tarbiyah IAIN Sunan Kalijaga.

Ahmad Mansur (2009). Metode Penelitian dan Teknik Penulisan Laporan Karya. Ilmiah, Universitas Padjajaran, Bandung.

Farhidian. R. (2002). Menjadi Orang Tua Pendidik. Jakarta. PT Al-Huda. 